\title{
Body Mass and Physical Performance in Urban Indonesian Children 10 - 12 Years
}

\author{
Sarashvati A. Sasongko*, Gustaaf P. Sevenhuysen ${ }^{\star \star}$
}

\begin{abstract}
Abstrak
Telah dipelajari massa tubuh dan kemampuan fisik 120 orang anak usia 10 - 12 tahun di Jakarta. Massa tubuh dinyatakan dengan standar berat badan/tinggi badan, indeks massa tubuh dan indeks berat badan/tinggi badan. Kemampuan fisik diukur dengan tes kesegaran jasmani menurut Rost dengan menggunakan ergocycle. Ditemukan bahwa status gizi subyek cukup baik sehingga tidak mempengaruhi kemampuan pada tes aerobik. Anak yang mempunyai massa tubuh paling besar memperlihatkan kemainpuan fisik yang paling rendah. Indeks berat badan - tinggi badan menunjukkan hubungan yang bermakna pada kedua kelompok. Aktivitas fisik mendukung tercapainya tingkat kesegaran jasmani yang lebih tinggi pada anak laki-laki.
\end{abstract}

\begin{abstract}
The body mass and physical performance of 120 urban children 10 to 12 years of age were studied in Jakarta. The body mass indeces analyzed were Weight-for-Height $(W / H)$, Body Mass Index (BMI) and Weight-for-Height Index (WHI). The physical fitness was assessed by the Rost's method using an ergocycle. The results indicate that the nutritional status of all subjects was sufficiently high for there to be little influence on their performance in aerobic fitness test. Subjects with the highest body mass performed at the lowest level. Weight, expressed as WHI, contributes significantly for both boys and girls, while habitual physical activity is an important predictor only among the boys.
\end{abstract}

Keywords : Physical fitness, Maximal oxygen uptake, Body mass index, Weight-for-height, Adolescent

\section{INTRODUCTION}

Human resources are an important part of economic productivity and improved physical fitness has been given increased attention as it relates to better work performance. ${ }^{1,2,3,4}$ To attain desire levels of physical performance, the human body requires food for development and maintenance and nutrition plays a role in physical performance. ${ }^{5}$ The relationship between nutritional status and physical performance has been demonstrated by a number of studies which showed the detrimental effects of undernutrition in childhood on work capacity as adults. ${ }^{1,3,6}$

A most commonly used physical fitness test involves the measurement of cardiopulmonary function during exercise. ${ }^{7,8}$ It is possible to equate fitness with cardiorespiratory endurance as measured by maximal aerobic power or maximal oxygen uptake. ${ }^{9}$ The max- imal oxygen uptake reflects the functional adaptability of the whole organism and is the result of numerous physiological responses. ${ }^{7,8,9}$ In its broadest sense, physical fitness reflects the physical working capacity or simply the working capacity of an individual and these terms are often used interchangeably. ${ }^{10}$

It is difficult to determine adolescent nutritional status from anthropometry due to the growth spurt which occurs at different ages among children. ${ }^{11}$ The World Health Organization recommends that the Body Mass Index (BMI) is used to report weight-height relationships until a better indicator is available to indicate body fatness. ${ }^{12}$ Meanwhile, a new index of weight-for-height (WHI) has been proposed by Chinn et al. ${ }^{13}$ This study resports the relationships of either index with a test of physical fitness which is used as a functional test of nutritional status, in a group of male and female school children in urban Jakarta.

\footnotetext{
* East Jakarta District Health Office, Jakarta, Indonesia

** Department of Foods and Nutrition, University of Manitoba, Winnipeg, Canada
} 


\section{MATERIALS AND METHODS}

Subjects were 60 male and 60 female school children aged 10 to 12 years from a private school (SD St Antonius I) and a group of public schools (SD Pondok Bambu 013, 014 and 015) in East Jakarta. Two different types of schools were chosen with the aim of including a relatively wide range of values as the socioeconomic statuses of parents differ. From both schools, equal number of subjects were randomly selected from children with heights over $1.40 \mathrm{~m}$, which was the minimum height required to operate an adult ergocycle (see Table 1)

The study was conducted according to criteria approved by the Ethical Review Committee of the University of Indonesia. Informed consent was obtained from the parents of each subject. Physical examinations and interviews during home visits were carried out to identify any past or current medical conditions that would prevent or hinder the child completing the physical fitness test.

Anthropometric measurements were measured with the subjects wearing shorts and in bare feet. A platform beam balance was employed to measure weight with an accuracy of 100 grams. Height was measured using a wall mounted microtoise gauge to the nearest $0.1 \mathrm{~cm} .{ }^{14}$ Weight-for-height (W/H: weight/ height). Body Mass Index (BMI: weight/height ${ }^{2}$ ) and Weight/Height Index (WHI: weight-9/height ${ }^{3.7}$ ) were calculated. ${ }^{15}$

The physical performance test was carried out according to the method of Rost, ${ }^{16}$ modified for submaximal test under field conditions. The subject was asked to perform consecutively several different workload trials starting form 25 Watt $(150 \mathrm{kpm})$ with an increment of 25 Watt on a Monark mechanical brake cycle ergometer. The pedalling rate was maintained at 60 per minute which was constantly checked from the built-in speedometer and each work trial lasted 2 minutes. The apical heart rate was determined using a stethoscope for 30 seconds after $11 / 2$ minutes of each work load. All the children were encouraged with competitive motivation to perform the indicated consecutive work trials until the heart rate was at least 170 beats/minutes which is approximately $85 \%$ of the maximal heart rate of 10 to 12 -year-old children ${ }^{17}$ or until he/she was exhausted or could not continue. Oxygen uptake in mililiters was from the load achieved by the subject, using the formula : $350+12 *$ load (Watt). The resting oxygen uptake is estimated at $350 \mathrm{ml}$ and the increase in uptake perminute per Watt is approximately 12 milliliters. ${ }^{16}$ Maximal oxygen uptake, $\mathrm{VO}_{2} \max$, was calculated by dividing $\mathrm{VO}_{2}$ by body weight. ${ }^{7}$
Habitual physical activity assessment was based on time motion analysis method, ${ }^{10}$ in which each subject recorded his/her activities for 3 consecutive days. To increase accuracy, in the forms complete by the subjects prompted entries for each 15-minute period during the day. ${ }^{18}$ Parents and physical education teachers were interviewed to confirm the data recorded by the child. The activities recorded were classified according to the standard activity types in three categories : light, moderate and heavy activities. ${ }^{7,8}$ The average time spent in moderate and heavy activities was used as an indicator of habitual activity in subsequent analysis.

Dietary intake assessments were obtained from food records kept by each subject over three consecutive days. The intake data was checked with the subject's mother/care-taker during an interview in the home. Energy and nutrient contents of the foods reported were calculated from the Indonesian Food Composition Tables. ${ }^{19}$ The hemoglobin level was determined by cyanhemoglobin method and the hematocrite by microhematocrite method. ${ }^{14}$

Regression analysis was used to determine the performance of body mass indices in relation to height, as well as to determine the relative contributions of body mass indices, energy intake and activity to $\mathrm{VO}_{2}$ max values. MANOVA analysis was performed to check the association of independent variables on the combined changes of $\mathrm{VO}_{2} \max$ and load. The Number Cruncher Statistical System (NCSS) was used for all statistical analyses.

Table 1. Age, anthropometric, $\mathrm{VO}_{2} \max$ and nutrition related data. (mean, $\pm S D$ )

\begin{tabular}{lcc}
\hline & $\begin{array}{c}\text { Female } \\
\mathrm{n}=60\end{array}$ & $\begin{array}{l}\text { Male } \\
\mathrm{n}=60\end{array}$ \\
\hline Age (mos) & $137.4 \pm 8.2$ & $140.9 \pm 8.7$ \\
Weight (kg) & $38.2 \pm 8.4$ & $37.8 \pm 7.6$ \\
Height (cm) & $146.2 \pm 4.8$ & $145.4 \pm 4.8$ \\
$\mathrm{BMI}\left(\mathrm{w} / \mathrm{ht}^{2}\right)$ & $17.8 \pm 3.39$ & $17.8 \pm 3.08$ \\
VO $2 \mathrm{max}(\mathrm{ml} / \mathrm{kg} / \mathrm{min})$ & $33.3 \pm 5.3$ & $38.2 \pm 6.3$ \\
Hemoglobin $(\mathrm{g} / \mathrm{dl})$ & $12.9 \pm 0.9$ & $13.1 \pm 1.1$ \\
Energy intake $(\mathrm{cal})$ & $2217.8 \pm 719.1$ & $2325.4 \pm 739.8$ \\
Activity time $(\mathrm{min})$ & $34.8 \pm 16.0$ & $51.4 \pm 20.4$ \\
\hline
\end{tabular}

\section{RESULTS}

Weight for height indices, calculated separately for boys and girls, were not independent of height as shown in Figure 1. The plots of height against the 
deviation of the respective index from its mean value show a slight association with height in all cases. The regression estimate for weight-for-height $(\mathrm{W} / \mathrm{H})$ was significantly different from zero for both boys and girls. Though both BMI and WHI show similar and neglible associations with height, WHI was selected for use in subsequent analysis on the basis of patterns shown in Figure 1.

The relationships of age and height or BMI are shown in Figure 2, which compares both indices for boys and girls with values recorded for children of the same age participating in the National Health and Nutrition Examination Survey (NHNES), in the United States. ${ }^{15}$ As shown in Figure 2, more than five percent of boys were found to have BMI values below the 5th percentile, and more than 5 percent of girls were found to have height values below the 5 th percentile. It was therefore assumed that several of the children below these 5 th percentile values showed inadequate growth due to reasons other than biological variation and possibly nutrition or health problems.

Figure 3 shows three relationships between the WHI, the maximum load achieved by the subject (watts $/ \mathrm{kg}$ ) and the $\mathrm{VO}_{2} \max (\mathrm{ml} / \mathrm{kg} / \mathrm{min}$ ), in a threedimensional plot. Maximum load and $\mathrm{VO}_{2}$ max show a positive relationship. However, both fitness measures are inversely related to the WHI. The same relationships were found for BMI with maximum load and $\mathrm{VO}_{2}$ max. The plot shows no apparent change in the relationship at very low values of WHI, indicating that the subjects with the lowest mass has the highest fitness. The pattern is the same for both boys and girls.

Table 2 shows strong negative correlations between $\mathrm{VO}_{2} \max$ and WHI, and the estimate of energy intake. Conversely, $\mathrm{VO}_{2} \max$ shows a strong positive relationship with the estimate of habitual activity. These relationships are expected.

Table 3 shows the results of regression analysis using the same variables in a multi-variate model. The model accounts for $62 \%$ and $69 \%$ of the variation in $\mathrm{VO}_{2}$ max among girls and boys respectively. WHI contributes significantly for both groups, while habitual activity is an important predictor only among the boys.

The regression analysis does not suggest that either energy intake or hemoglobin predict $\mathrm{VO}_{2}$ max. Nor do other variables that have been associated with nutritional status in other studies. Possible association between joint changes in $\mathrm{VO}_{2}$ max and maximum load with changes in height and $\mathrm{BMI}$ were tested with a manova procedure. The analysis showed no apparent effect from either height or BMI on the combination of $\mathrm{VO}_{2} \max$ and maximum load.
Table 2. Correlation coeflicients for $\mathrm{VO}_{2} \max$ and six selected variables

\begin{tabular}{lcc}
\hline & \multicolumn{2}{c}{ Vo $O_{2 m a x}$} \\
\hline Weight-for-height index & -0.7732 & Male \\
Energy intake & -0.4449 & -0.8054 \\
Activity lime & 0.3387 & -0.3986 \\
Age & 0.1367 & 0.5454 \\
Hemoglobin & -0.1266 & 0.3513 \\
Father's education & -0.1471 & -0.0622 \\
& & -0.3054 \\
\hline
\end{tabular}

Table 3. Multiple regression model with $\mathrm{VO}_{2} \max$ dependent and six independent variables

\begin{tabular}{lcc}
\hline & \multicolumn{2}{c}{$\mathrm{VO}_{2 \mathrm{max}}$} \\
& Patameter Estimate & $\mathrm{P}$ \\
\hline Females (n=60) & & \\
Weight-for-height index & -17.87834 & $0.0000^{*}$ \\
Energy intake & -2.400483 & 0.1785 \\
Age & $-0.209 \mathrm{E}-02$ & 0.9756 \\
Activity & 0.3815458 & 0.7263 \\
Hemoglohin & 3.817241 & 0.5936 \\
Father's education & $0.8477 \mathrm{E}-01$ & 0.4528 \\
& & \\
Males (n=60) & & \\
Weight-for-height index & -19.56125 & $0.0000^{*}$ \\
Energy inlake & -2.042743 & 0.3634 \\
Activity & $0.6678 \mathrm{E}-01$ & $0.0288^{*}$ \\
Age & 0.0516553 & 0.4646 \\
Hemoglobin & 0.209762 & 0.6736 \\
Father's education & 0.1006605 & 0.4764 \\
& & \\
\hline
\end{tabular}

\section{DISCUSSION}

The analysis of body mass indices shows that the performance of $\mathrm{W} / \mathrm{H}$ is not adequate for the group of subjects studied. The results suggest that $\mathrm{BMI}$ and WHI are less related to the height of the individual and may therefore be better indices to describe body mass differences between adolescents. BMI has been proposed as a suitable index by some researches. ${ }^{12,20}$

The numbers of subjects with either weight for height or BMI indices below those of children measured in the United States was lower than reported in other studies. ${ }^{21,22}$ It appears that the group of children selected for the study were of higher nutritional status than others in Indonesia, inspite of attending both upper-middle and lower socioeconomic class institution. A small number of subjects may have been compromised in growth, given the numbers that were shorter and lighter than the 5 th percentiles recorded for American children.

However the functional test of aerobic fitness showed an inverse relationship with body mass, also for individuals below the 5th percentile of height or BMI. The finding confirms those of other 

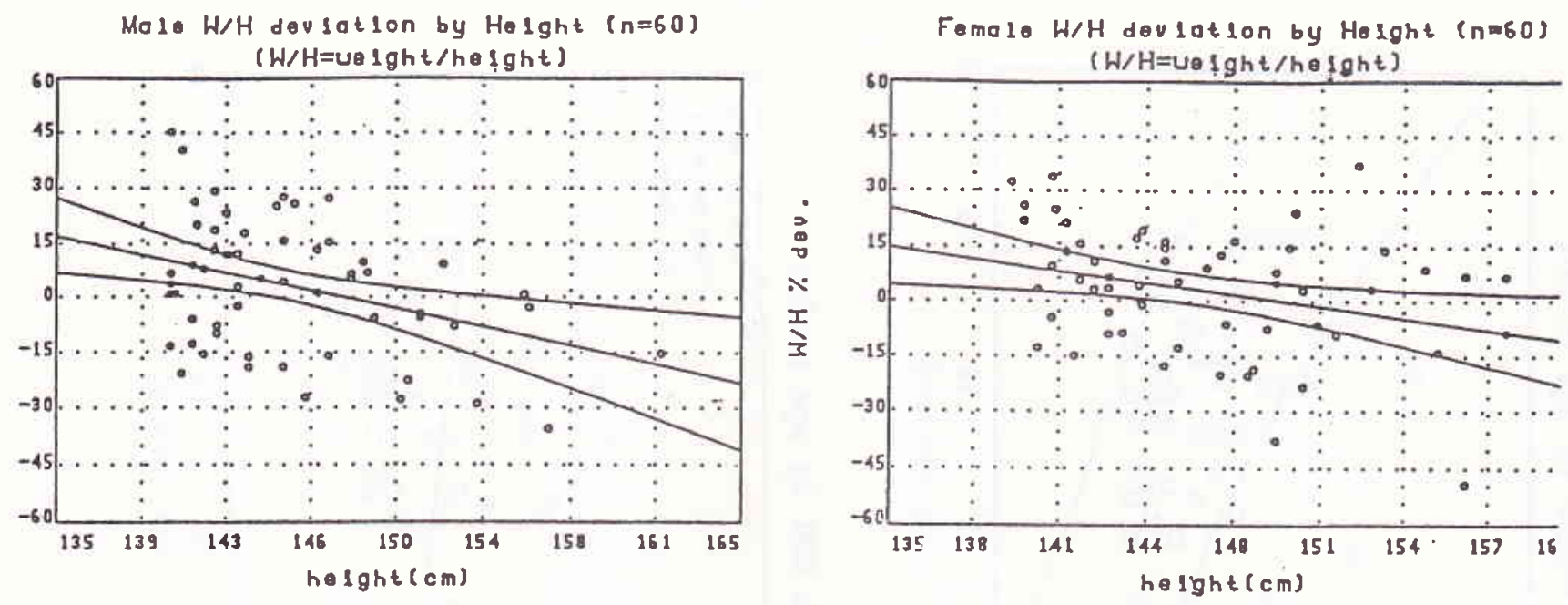

Male BMI devlation by Helght $(n=60)$ ( $B M I=U \theta 1 \mathrm{ght} / \mathrm{h} \theta \mathrm{lght} * \ldots 2$ )
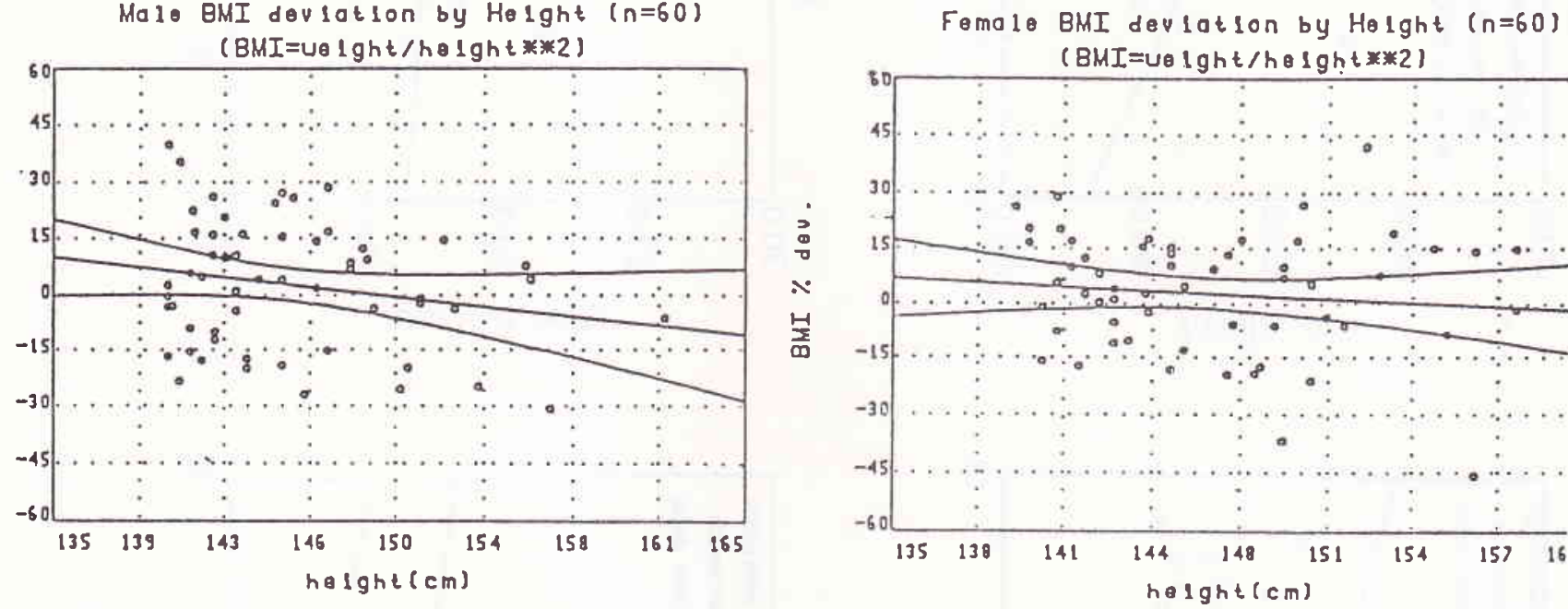

Malo WHI deviotion by Helght $(n=60)$ ( WHI= ( ve I ght-g) /he $1 \mathrm{ght}$ w3.7)
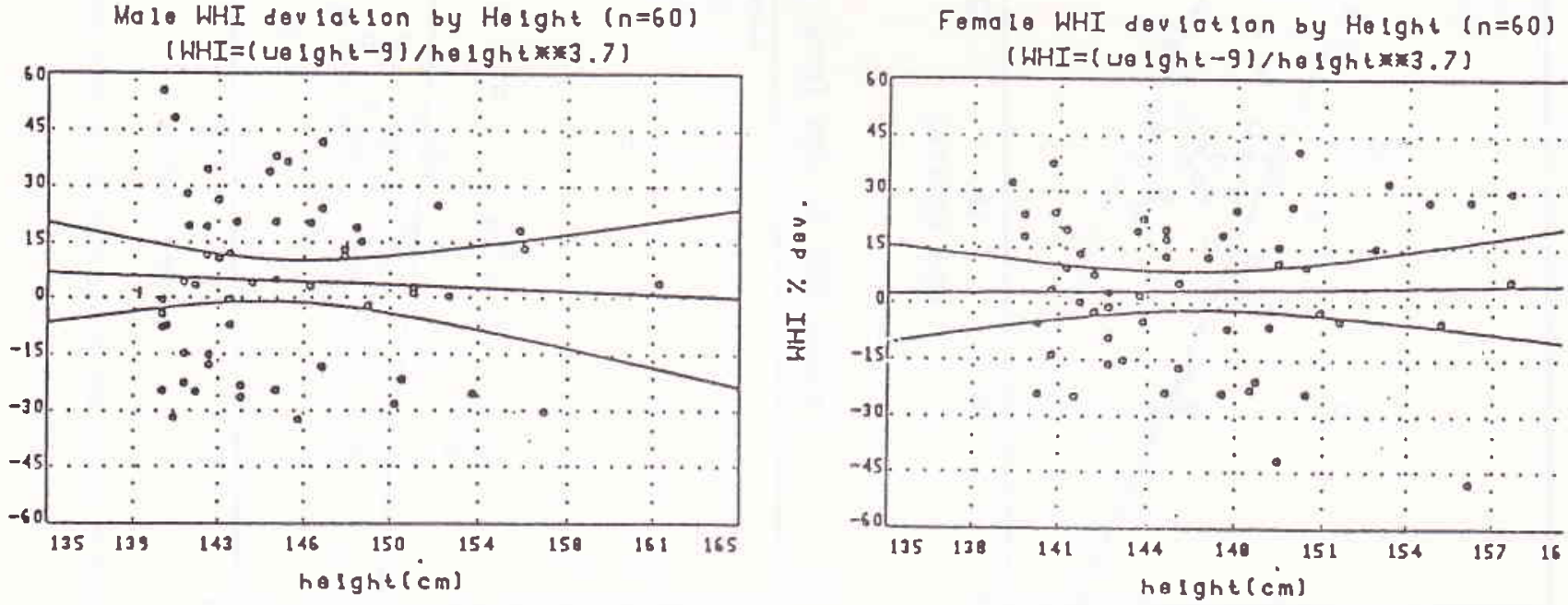

Figure 1. W/H, BMI and WHI deviation by height of female and male subjects 

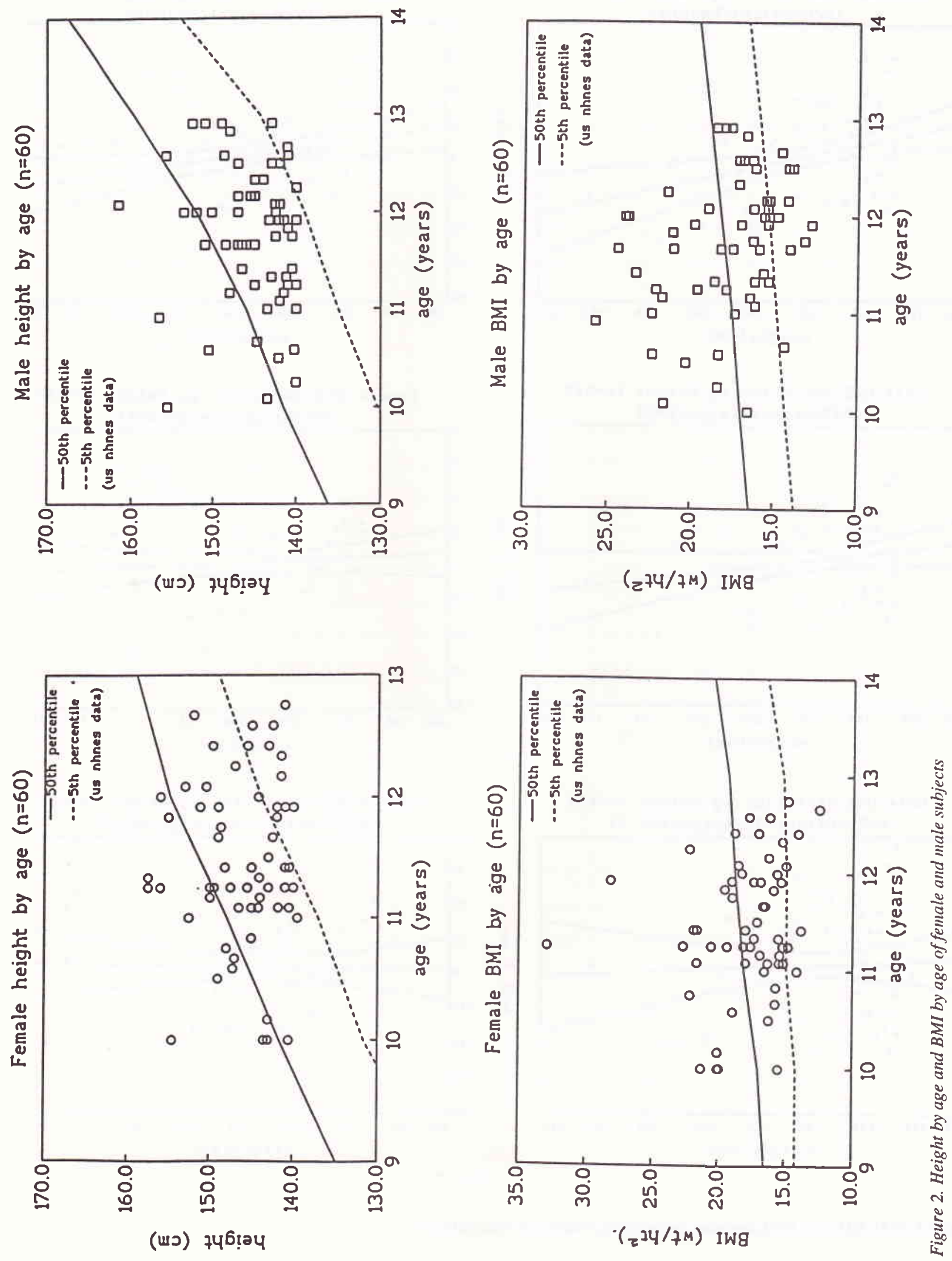
Female VO2max (ml/kg) by lood (watt/kg: and WHI ([ut-9]/ht**3.7) $(n=60)$

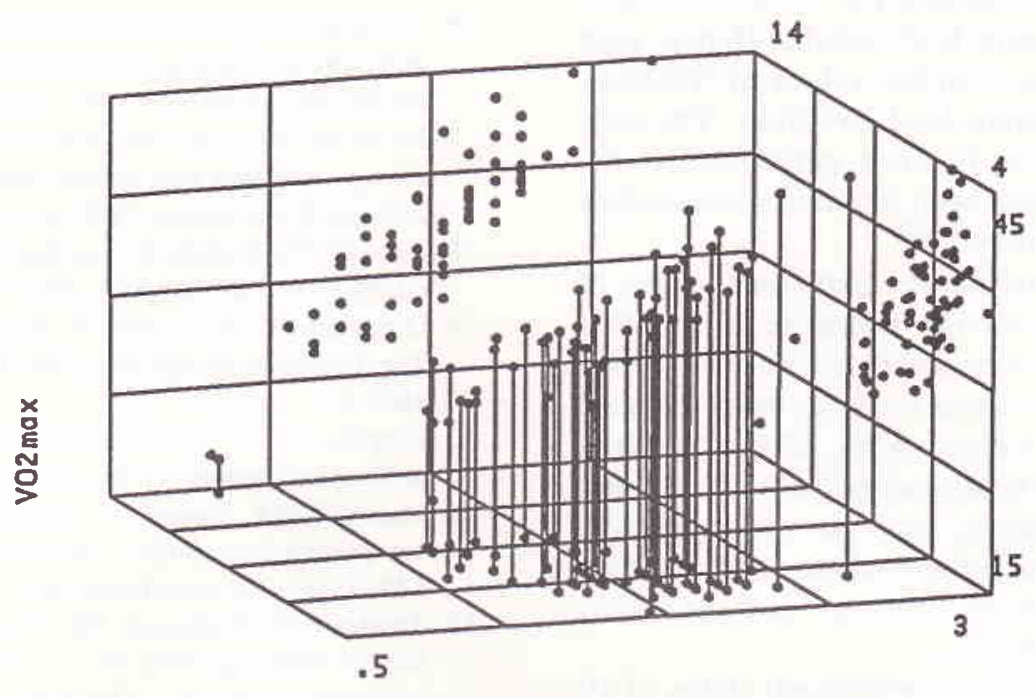

WHI ungto

$\operatorname{mox} .100 d$

Female

Mole V02max (ml/kg) by lood (watt/kg) and WHI ([ut-9]/ht***3.7) $(n=60)$

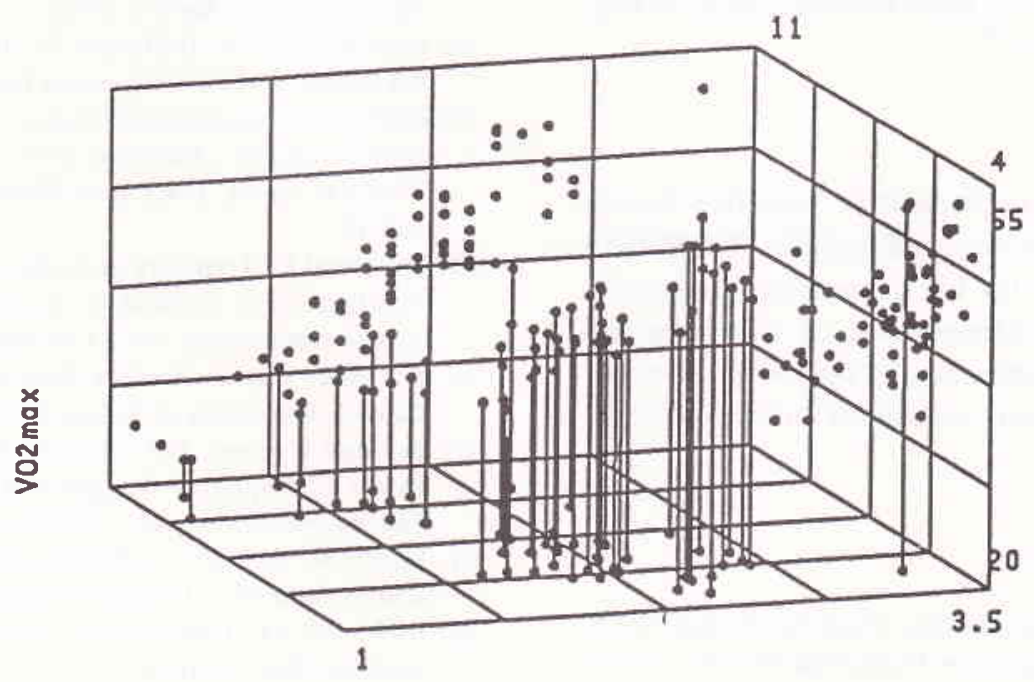

WHI undt:

$\operatorname{mox} \cdot 100 d$

Male

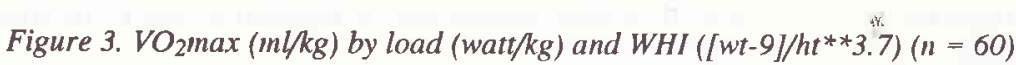


authors. $^{2,10,23}$ The inverse relationship can be explained by the fact that subjects with low body mass are leaner, with a higher proportion of metabolically active tissue per kilogram bodyweight. Hence, lean subjects are able to reach higher values of VO2max $(\mathrm{ml} / \mathrm{kg} / \mathrm{min}$ ) and maximum load (watt $/ \mathrm{kg}$ ). The subjects with the highest body mass performed at the lowest level. This has also been found in some studies on fitness of obese children. ${ }^{24,25}$

The results indicate that the nutritional status of all subjects was high enough for there to be little influence on their performance in an aerobic fitness test, regardless of low values for body mass indices. All three body mass indices, WHI, BMI abd W/H, demonstrated the same relationship. Neither were any nutrition related estimates, such as energy intake, hemoglobin levels or father's education important in explaining the variation in $\mathrm{VO} 2 \mathrm{max}$ and maximum load achieved by the subjects.

The study shows that the nutritional status of 10 to 12 years old children form two different types of schools in urban Jakarta was comparable to the status of children measured in the NHNES survey in the United States. The functional test of nutritional status demonstrated that all subjects were able to perform adequately and that habitual physical activity contributed in higher fitness level among boys. It may be that a higher level of habitual physical activity especially in girls will increase their fitness levels, as suggested in several studies. ${ }^{24,25}$

\section{Acknowledgement}

The authors would like to thank Drs. Soemilah Sastroamidjojo, Director of Teaching, SEAMEO-TROPMED, University of Indonesia for her support in writing this article; Zainal Abidin, Department of Nutrition and Minarma Siagian, Department of Physiology, University of Indonesia, for their assistance in the actual research.

\section{REFERENCES}

1. Satyanarayana K, Nadamuni NA, Chaterjee B, Rao, BSN Body size and work output, Am J Clin Nutr 30; 1977: 322-5.

2. Satyanarayana K, Naidu AN, Rao N. Nutritional deprivation in childhood and the body size, activity, and physical working capacity of young boys, Am J Clin Nutr 32; 1979: 1769 75 .

3. Spurr GB, Dahners HW, Barac-Nieto M. Marginal malnutrition in school-aged Colombian boys : Functional consequences in maximum exercise, Am J Clin Nutr 37; 1983:834-47.

4. Stroot P. A priority for the WHO : Promoting healthy ways of life, Am J Clin Nutr 49 no 5 (supp), 1989; 1063-964.
5. Whitney EN, Cataldo CB, Rolfes SR. Understanding normal and clinical nutrition, 2nd ed, West Publishing, St Paul, 1987, 222-3.

6. Areskog NH, Selius R, Valquist B. Physical work capacity and nutritional status in Ethiopian male children and young adults. Am J Clin Nutr 1969; 22:471-9.

7. McArdle W, Katch FI, Katch VL. Exercise physiology, energy, nutrition and human performance, 2nd ed, Lea \& Febiger, Philadelphia, 1985, 3-513.

8. Astrand PE, Rodahl K. Textbook of work physiology, 3rd ed, McGraw Hill Book Co, New York, 1987, 523-76.

9. Georgiades G, Klissauras V. Assessment of youth fitness : The European perspective, Am J Clin Nutr 49 (5):(supp), 1048-53.

10. Barr-Or O. Der praxis der sportmedizin in der kinderheilkunde Springer-Verlag, Berlin, 1986.

11. Marchall WA, Tanner JM, Puberty. In : Human growth - a comprehensive treatise 2 nd ed edited by Frank Falkner \& J.M. Tanner, Plenum Press, New York, 1986, 171-203.

12. Tienboon P, Walhquist ML, Rutishauser IHE. Early life factors affecting body mass index and waist-hip ratio in adolescence, As Pac J Clin Nutr 1, 1992, 21-7.

13. Chinn S, Rona RJ, Gulliford MC, Hammond J. Weight-forheight index in children aged 4-12 years. A new index compared to the normalized body mass index, Euro J Clin Nutr 1992, 46; 489-500.

14. Jellife DB. The assessment of the nutritional status of the community, WHO, 1966, 10-30.

15. US Department of Health and Human Services, National Center for Health Statistics, Anthropometric reference data and prevalence of overweight United States 1976-1980, National Health Survey Series 11 no 238, 1987.

16. Rost R, Heck H, Hollmann W. Die Fahrradergometries in der Praxis, 2nd ed, Universitat Dortmund, 1984, 3-10.

17. Barr-Or O. Special consideration of exercise in children and adolescents, in : Nutrition and exercise edited by Myron Winnick, Ist ed, 1986, John Wiley \& Sons Ltd, New York, 105- 15 .

18. Bouchard C, Tremblay A, Leblanc C, Lortie G, Savard R, Therlaut $G$. A method to assess energy expenditure in children and adults, Am J Clin Nutr, 1983; 461-7.

19. Nio OK. Daftar Analisa Makanan (Food Composition Tables), University of Indonesia, Jakarta, 1992.

20. Rolland-Cachera MF, Sempe M, Guilloud-Bataille M, Patois E, Pequignot-Guggenbuhl F, Fautrad V. Adiposity indices in children, Am J Clin Nutr 1982, 36; 178-84.

21. Enoch M, Hatifah, Syafruddin. Body weight and height of school children in Depok, Medika 1990, 16; 633-41.

22. Rilantono LI. Tredmill test in school children in Jakarta, Medika 1992, 18;16-8.

23. World Health Organization, A joint FAO/WHO/UNU expert consultation report, WHO Report Technical Series 724, WHO, Geneve, 1985, 50-74.

24. Huttunen NP, Knip M, Paavilainen T. Physical activity and fitness in obese children, Int J Obesity 1986, 10;519-25.

25. Tremblay A, Despres JP, Leblanc C, Craig CL, Ferris B, Stephens T, Bouchard C. Effect of intensity of physical activity on body fatness and fat distribution, Am J Clin Nutr 1990, 51;153-7. 